\title{
Discourses on the nursing and psychiatric nurse models, published in the Annals of Nursing (1933-1951)
}

\author{
Discursos sobre os modelos de enfermagem e de enfermeira \\ psiquiátrica nos Annaes de Enfermagem (1933-1951) \\ Discursos sobre modelos de enfermería y de enfermería psiquiátrica \\ en los Annaes de Enfermagem (1933-1951)
}

\author{
Michelle de Macedo Pereira ${ }^{a}$ \\ Maria Itayra Padilhab \\ Alexandre Barbosa de Oliveirac \\ Tânia Cristina Franco Santos ${ }^{d}$ \\ Antonio José de Almeida Filho \\ Maria Angélica de Almeida Peres ${ }^{f}$
}

DOl: $\quad$ http://dx.doi.org/10.1590/19831447.2014.02.25736

Nurse. Member of the Brazilian Center for Research of the History of Nursing (Nuphebras). Rio de Janeiro/ RJ, Brazil

${ }^{b}$ Nurse. Post-Doctorate in Nursing. Faculty of the Nursing Department and the Post-Graduate Nursing Program of the Federal University of Santa Catarina Leader of the Study Group of Nursing and Healthcare Knowledge (GEHCES). CNPq Researcher. Florianópolis/SC, Brazil.

c Nurse. Doctor of Nursing. Associate Professor of the Anna Nery School of Nursing of the Federal University of Rio de Janeiro (EEAN/UFRJ). Member of Nuphebras. Rio de Janeiro/RJ, Brazil

${ }^{d}$ Nurse. Post-Doctorate in Nursing. Associate Professor of EEAN/ UFRJ. Member of Nuphebras. CNPC Researcher. Rio de Janeiro/RJ, Brazil.

e Nurse. Doctor of Nursing. Associate Professor of EEAN/UFRJ. Member of Nuphebras. Rio de Janeiro/RJ Brazil.

${ }^{f}$ Nurse. Post-Doctorate in Nursing. Adjunct Professor of EEAN/UFRJ. Member of Nuphebras and GEHCES. Academic Coordinator for the EEAN/UFRJ Documentation Center. Rio de Janeiro/RJ, Brazil.

\section{ABSTRACT}

Social-historical study aimed at discussing the nursing and psychiatric nurse models, from the discourses published in the Annals of Nursing. The historical sources were articles published in the Annals of Nursing journal, from 1933 to 1951. An analysis of the discourse was subsidized by the genealogy of power by Michel Foucault. The analysis showed that the discourse on nursing and the psychiatric nurse, in the first half of the 20th century, is set, on one side, by the propositions used by psychiatrists, who sought to reiterate stereotypes and vocations to practice nursing, and, on the other side, by the active participation of nurses seeking to legitimize expertise for psychiatric nursing. It was concluded that the discourses analyzed defined a psychiatric care focused on the nurse and not the rest of the nursing staff, at that time.

Descriptors: Nursing. History of Nursing. Psychiatric nurse.

\section{RESUMO}

Estudo histórico-social que objetivou discutir os modelos de enfermagem e de enfermeira psiquiátrica, a partir dos discursos publicados nos Annaes de Enfermagem. As fontes históricas foram artigos publicados na revista Annaes de Enfermagem, de 1933 a 1951. Foi utilizada a análise do discurso subsidiada pela genealogia do poder de Michel Foucault. A análise evidenciou que o discurso sobre a enfermagem e a enfermeira psiquiátrica na primeira metade do século XX, se configurou, de um lado, por proposiç̧ões que foram utilizadas por médicos psiquiatras, que visavam reiterar vocações e estereótipos para a prática da enfermagem, e, de outro lado, pela participação ativa de enfermeiras que buscavam legitimar um saber especializado para a enfermagem psiquiátrica. Concluiu-se que os discursos analisados definiram um modelo de assistência psiquiátrica voltado para a enfermeira e não para os demais trabalhadores de enfermagem à época.

Descritores: Enfermagem. História da enfermagem. Enfermagem psiquiátrica.

\section{RESUMEN}

Estudio histórico y social que objetivó discutir el modelo de enfermería y de enfermera psiquiátrica, a partir de los discursos publicados en los Anales de Enfermería. Las fuentes históricas fueron artículos publicados en la revista Annaes de Enfermagem, de 1933 a 1951. Se utilizó el análisis del discurso, subsidiado por la genealogía del poder de Michel Foucault. El análisis evidenció que el discurso sobre la enfermería y la enfermera psiquiátrica en la primera mitad del siglo XX, se configuró, de un lado, por proposiciones que fueron utilizadas por médicos psiquiatras, que visaban reiterar vocaciones y estereotipos para la práctica de la enfermería, y, de otro lado, por la participación activa de enfermeras que buscaban legitimar un saber especializado para la enfermería psiquiátrica. Se concluyó que los discursos analizados definieron un modelo de asistencia de enfermería psiquiátrica direccionado hacia la enfermera y no hacia los demás trabajadores de enfermería a la época.

Descriptores: Enfermería. Historia de la enfermería. Enfermería psiquiátrica. 


\section{口INTRODUCTION}

The creation of the Brazilian League for Mental Hygiene (Liga Brasileira de Higiene Mental (LBHM)), in 1923, brought the influence of the North American mental hygiene movement to Brazil, which prioritized the preventative vision of mental illnesses and thus sought professional training, teamwork and treatment outside the scope of hospitalization, in order to prevent mental illness ${ }^{(1,2)}$. The initial goals of this movement, conceived by Clifford Beers and collaborators, in 1907, were to improve treatment and fight the causes of mental illnesses. Soon after, a third purpose arose: conservation of the mental health of people deemed "normal," who should receive care through home visits ${ }^{(1-3)}$.

Reformulating psychiatry in the first half of the $20^{\text {th }}$ century, the LBHM proposed sanitary control of the population, one of the modes found by the state to guarantee economic productivity ${ }^{(1)}$. Psychiatric care began to focus on the healthy individual and not the sick one. Prevention was practiced through the reformulation of psychiatric services and improvement of healthcare professionals $s^{(1-3)}$.

The concept of mental hygiene, used in the mid $20^{\text {th }}$ century, had a preventative vision of mental illnesses and thus sought professional training, multi-professional teamwork and treatment outside the scope of hospitalization, in order to prevent mental illness ${ }^{(3,4)}$.

The profession of nursing had already been established within the legally established educational standards, however, the practice and teaching of psychiatric nursing was compromised by the hospital-centric model, which led to care provided in specialized healthcare institutions. Therefore, the LBHM presented a care qualification alternative, which resulted in a nursing and psychiatric nurse model that resonated with mental hygiene ideals $s^{(5)}$.

The transformations in psychiatric nurse practices occurred alongside the evolution of medical practices and attempts at incorporating new psychiatric treatment policies and techniques ${ }^{(4)}$. Nursing care proposals became part of mental hygiene, driving it toward the prevention of mental illness, through home visits and outpatient care, stimulating a transformation in the psychiatric nursing model, which, until then, had been driven toward asylum treatment.

The subject of this study is the nursing and psychiatric nurse model, from discourses published in the Annals of Nursing, from 1933 to 1951. The objective is to discuss the nursing and psychiatric nurse models, from the discourses published in the Annals of Nursing.

\section{METHODOLOGY}

A historical-social study produced by the Brazilian Center for Research of the History of Nursing (Núcleo de Pesquisa de História da Enfermagem Brasileira), whose historical sources were articles published in the Annals of Nursing, the first nursing periodical in Brazil, which was in circulation from 1932 to 1954, when its name was changed to the Brazilian Nursing Journal (Revista Brasileira de Enfermagem). Texts that had some reference to psychiatry and/or psychiatric nursing, from August to September 2011 were chosen from the entire collection of the Annals of Nursing belonging to the collection from the Anna Nery School of Nursing. The search found nine articles, six of which were presented as direct citation, since they dealt specifically with the subject of this study. The other articles did not show the nursing and psychiatric nurse models, however they contextualized mental healthcare at the time. The use of these articles as primary sources serves the purpose of document analysis in the historical method, in which a text is always seen as carrying a discourse and, thus considered, represents the enunciation of a group ${ }^{(6)}$, particularly of healthcare professionals involved with psychiatry and mental hygiene.

We used Michel Foucault's discourse analysis procedure ${ }^{(6)}$, from the reading of the texts and determination of discourse units, which were grouped by similarities, thus building categories. As a theoretical framework, we used Foucault's genealogical analysis( ${ }^{(7)}$ that, when considering the discourse as determined by a regularity, allows something to appear as true and seeks to understand the discourse through an analysis of the knowledge, since "there is no knowledge without a definite discursive practice, and all discursive practice can be defined by the knowledge that it forms ${ }^{\prime \prime(6)}$. It also considered that the human groups, in their social relationships, develop a daily life that is full of power relationships that we intend to reveal in the discourses analyzed ${ }^{(7)}$.

From the analysis of the discourses contained in the sources selected, the following categories emerged: 1) Psychiatric nursing model; 2) Psychiatric nurse model.

This article is the result of the research project "Teaching of Psychiatric Nursing at the Anna Nery School in the mid $20^{\text {th }}$ century," approved by the Ethics Committee on Human Beings of the Anna Nery Nursing School/São Francisco de Assis Teaching Hospital/Federal University of Rio de Janeiro, under the Opinion of the Protocol No. 064/2010 and is justified by the finding of difficulties of (re)producing discourses about psychiatric nursing practices in this period. 


\section{RESULTS AND DISCUSSION}

\section{Discourses about Psychiatric Nursing published in the Annals of Nursing}

In the period that the Annals of Nursing circulated, fifty issues of the magazine were published, nine of which contained articles about psychiatric nursing. The first article was published in 1933 and for thirteen years there were no publications about this matter, which was only addressed again with an annual article in 1946, 1947, 1948 and 1950. In 1951, four articles were published, having no publication in 1949, nor were any articles published from 1952 to 1954.

We can confirm that the matter of psychiatric nursing started to become more explored in 1946, demonstrating that the issues inherent to mental illness were configured as the subject of concern of nurses, which began to disclose them in their periodical. Some reasons justify this concern: first due to the high number of people hospitalized in psychiatric institutions, and then due to the lack of competent staff and good hospital facilities and, finally, due to the lack of suitable measures for preventing and treating mental illnesses ${ }^{(8)}$.

This situation is related to the end of World War II, in 1945, when the needs of mentally ill patients became a priority for medical science. The end of the War awoke a concern for the mental aspects of the population, adding to the other issues regarding healthcare that appeared at the time, such as the founding of the World Health Organization, which included psychological well being, which related to physical and social well being in its definition of health ${ }^{(3,9)}$.

Regarding the authorship of the articles, we identified three professional categories, made up of: physicians, nurses and nursing students.

The authors who were doctors were the psychiatrists Plínio Olinto, one of the founders of the LBHM, and Joy Arruda, a professor of Psychiatry and Mental Hygiene of the Anny Nery School; the Doctor of Public Healthcare, Howard Lundy and the sanitarian, Malta Santos. These authors dealt with psychiatric nursing care and the characteristics of the psychiatric nurse. Howard Lundy and Malta Santos related psychiatric nursing care to public health.

Therefore, there is an interest from physicians in improving nursing preparation for a specific type of care, as well as a movement in favor of nurses working on issues of mental hygiene, which sought, mainly, the prophylaxis of mental illnesses in the community. This fact demonstrated a direct relationship of a nurse's work with public health, in which nursing care and sanitary education are intercon- nected, the former being considered one more asset to the effectiveness of educational actions $\mathbf{s}^{(8,10)}$.

Nursing students participated through a translation done in 1946 by Amália Corrêa de Carvalho and a case study written in 1950 by Mery Aidar, both students from the São Paulo School of Nursing. The two texts dealt with psychiatric nursing care.

As for the articles written by nurses, we had another article by Amália Corrêa de Carvalho (1947), this time as a professor at the São Paulo School of Nursing; an article by Elisabeth Barcellos (1951), also a professor at the São Paulo School of Nursing; an article by Ermengarda Faria Alvim (1951), a nurse at the Anna Nery School and assistant of the Nursing Division of the Special Public Healthcare Service (SESP). These articles dealt with psychiatric nursing care, while the article by Ermengarda Faria Alvim related psychiatric nursing care with Public Health.

In an excerpt from the study, the discourse by the nurses followed the medical discourse and both approached the theme of psychiatric nursing care grounded in scientific knowledge and the relationship of the public healthcare nurse with mental hygiene actions, justified by the preventative approach and outpatient treatment, according to the precepts of the LBHM.

All knowledge (scientific or not) is only possible at a certain historical moment, because there is a space of order that allows for $\mathrm{it}^{(6)}$. However, the publications by nurses are related to the historical moment in which they were produced, when improvement of the psychiatric nursing care situation was being pursued, seeking the teaching of the specialty and differentiation, from training, of the care provided by registered nurses.

\section{Psychiatric nursing model according to the discourses published in the Annals of Nursing}

At the beginning of the $20^{\text {th }}$ century, psychiatric care was focused on prejudices that involved the overcrowding and precarious conditions of institutions, of the stereotypes about mentally ill patients, as well as the low wages, which led to the devaluation of the nursing professional that worked in this area ${ }^{(9,11)}$.

In the 1930s, the discourse about psychiatric nursing placed it in three distinct settings with differentiated actions: "in the doctor's office, the nurse began his or her work by completing a brief, yet true and complete, record, which was the basis for the medical exam, (...). In home care, the nurse became a visitor, in this step, visiting her patient, providing instructions about treatment. The nurse's visit should be short, not friendly, remaining standing and 
not accepting any favors. At the hospital, the nurse is the patient's companion at all times, administering medication, feeding the patient, bathing him or her, putting the patient to sleep, suffering with him or her if need be $e^{(11) ! "}$

With the conception of the LBHM, psychiatric nursing care was also considered outside of the hospital. The space outside the hospital was considered to be an upgrade and development of nursing, upon promoting ideas considered modern at the time regarding the role of the psychiatric nurse, including his or her role in doctors' offices and home visits, which supported the Mental Hygiene Program, which focused on the prevention, eugenics and education of the individuals ${ }^{(12)}$.

The disciplinary procedure has principles that determine each person's roles and puts each individual in his or her place, available to bodies in space and time, making a circular network of relationships, which functions, at the same time, as a power technique and process of knowledge ${ }^{(6,7)}$.

Beginning in 1944, the National Service for Mental IIInesses, pressured by the increasing costs of psychiatric hospitals, began broadcasting the ideas of outpatient treatment. Thus, what were known as mental hygiene outpatient clinics were created, and began to appear little by little in the state capitals, inspired by the concepts of the LBHM ${ }^{(2,3)}$.

The problems presented by the institutions were considered obstacles to good psychiatric nursing care: "the increasingly growing number of mentally ill patients has resulted in institutions that are too large for efficient administration and care suited to patient needs [...] Their buildings look like prisons and lack accommodations necessary for the treatment and comfort of the patient ${ }^{(8), "}$ i.e., they are institutions whose physical layout limits the interaction between mentally ill patients and society, as well as hinders nursing care. Another problem for care was the level of knowledge about psychiatry that the nurses and attendants had, which was considered low, and the compensation unappealing ${ }^{(8)}$. This can be seen in the discourse by one nurse: "Mentally ill patients are not treated well, because there still are not people qualified to deal with them rationally. We see full hospitals, but who really treats the patients? Simple people, with little education, who are not cultured, poorly paid, work long hours and are truly heroes, full of good will(13)".

This discourse presents, on one hand, the characteristics of the nursing staff present in the psychiatric hospitals, made up mostly of attendants, without any formal preparation. And, on the other hand, show the consequences of teaching nursing that has been standardized by the Federal Government since 1931, using the Anna Nery School as a model, which has not favored psychiatric nursing in its curriculum, not offering an internship in the area, which has kept registered nurses from psychiatric work ${ }^{(9)}$.

In the medical discourse, the objects of psychiatric nursing that were highlighted: carrying out physician's orders, maintenance of the routine of the pavilion, preparation of the patient for treatments and assisting their needs, in addition to fostering a hospital setting that is sane, calm and harmonious, with practical activities, making all of the physician's work easier ${ }^{(14)}$. In these ideas is the submission of the nursing actions to physicians' actions, which relates to the power relationships through a specific power technique that was called discipline or disciplinary power ${ }^{(7)}$.

Two of the articles analyzed featured the definition of psychiatric nursing. The first describes it as: "Psychiatric nursing means the care of patients who have mental disorders, manifested either by anomalous behavior, pathological thoughts, or misguided affects and feelings $s^{(14) . "}$ In the second, psychiatric nursing "is an art through which the nurse helps his or her patient, through all means possible, to become socially adjusted. It is not limited to any specific organ or apparatus of the human body, since it deals with the individual as a whole. In other words, the psychiatric nurse is interested in the physical well being of his or her patients, in their ideas about themselves, in their reactions to people that try to help them and in their adjustment to hospital routines, to other patients, and to their family and friends ${ }^{(15) . "}$

Analyzing the aforementioned definitions, we see that the first, arising from the medical discourse, guides toward the aspects inherent to the illness, as issues connected to behaviors and symptoms. Whereas the second, arising from the discourse of a nurse, highlights the needs of the patient, being understood as a whole, in that all his or her needs must be understood and met. The definition presented by the nurse carries a tone of knowledge of his or her area in that context, which would be reiterated with the passing of time as a profession that deals with caring for the health of another, emphasizing issues that involve the human being in its entirety ${ }^{(16)}$.

\section{Psychiatric nurse model according to the discourses published in the Annals of Nursing}

When dealing with the profile of a psychiatric nurse, the medical discourse highlighted that: "The psychiatric nurse needs to have some peculiarities that makes him or her different from other nurses(...) (12)."The following intellectual attributes were also considered important: "clear perception, capacity for clear fixation and attention, easy association of ideas, prepared reasoning and judgments, courage, pity, 
patience, weighted feelings, controlled emotions and no ardor ${ }^{(12) . " ~ S o ~ w e ~ a g r e e ~ t h a t ~ " t h e ~ m e d i c a l ~ d i s c o u r s e ~ m o d e l s ~}$ the expected and stereotyped behavior of nurses, helping explain the representation of this submissive and silent behavior in the daily life of nurses ${ }^{(17) ! "}$

Furthermore, a psychiatric nurse is required to have an attitude that is seen as happy, active and willing, always trying to help his or her patients, talking to them warmly, "because that is how they will forget a little about their suffering, and will trust the nurse ${ }^{(11) . " W e}$ noticed that the qualities attributed to the psychiatric nurse were well defined by the physician, with respect to intellectual, moral, affective and physical aspects, describing a virtuous person, which comes closer to an angel figure than a professional. The political investment of the body relates, in a complex and reciprocal fashion, to its economic use. To be constituted as a work force, the body must enter into a system of subjection: "the body only becomes a useful force if it is, at the same time, a productive body and a submissive body ${ }^{(18) ! "}$

It was also emphasized that psychiatric nursing had special characteristics that distinguished it from general nursing and its main objectives needed to address "winning over the well being of the patient and re-establishing

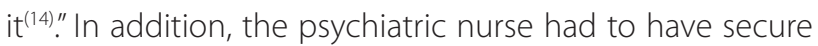
knowledge about the nature of his or her work, as well as have a series of personality traits to be able to correctly perform his or her functions ${ }^{(14)}$. And, among the general qualities, the psychiatric nurse would have to have: discretion, sympathy, patience, goodness, sincerity and a pleasant personality. The nurses' attitudes should always be moderate, modest, full of goodness and patience ${ }^{(14)}$.

When speaking specifically about the actions of mental hygiene nurses, the medical discourse praised their submission to the knowledge of the physician, stating that "this stems from the instructions that derive from their knowledge of physiology, psychology, pathology, psychiatry and sociology, being up to the nurse to only apply the indications, at the proper time and place, the physician only registering the benefit of what he or she indicated. The nurse must be obedient, following all the rules and comply without arguing with the orders given ${ }^{(12) . " T h e ~ m e d-~}$ ical discourse reinforced that his or her knowledge was superior and the nurse must obey and cooperate with the physician, characterizing a disciplinary power technique to make him or her the dominant class.

In the nurses' discourse, the professional allocated to psychiatric care would have to have specialized preparation, not only in the scientific aspect, but also in the psychological aspect: "The person that cares for a mentally ill patient, in addition to essential scientific preparation, with good psychological and psychiatric knowledge, must also have: 1 - reasonable emotional balance; 2 - good health; 3 - very developed capacity for observation. This does not place much emphasis on qualities that are also important, and which generally result from the first 3 , being: a dignified and calm attitude, soft but firm movements, a pleasant appearance, and a moderate tone of voice ${ }^{(13) . "}$ All of these qualities are important, especially when the patient is agitated, since, using these qualities, the nurse will be able to understand the patient and manage to lead him or her toward a constructive, rather than destructive activity ${ }^{(13)}$.

The practice of psychiatric nursing has appeared justified by the scientific background that you would expect from a professional with a degree: in the first place, the nurse observes behaviors that distinguish his or her patient from well adjusted individuals; second, he or she should have the ability to understand signs, symptoms and reactions observed and third, he or she should be able to write down these observations with such precision that other people will be able to benefit from them; and lastly, he or she should make a psychiatric nursing plan that follows the therapeutic objectives so that each patient finds, within himself or herself, that which he or she needs, individually ${ }^{(15)}$.

With the end of World War II, there was a strong call for research about mental disorders, "because everyone can see that, even with physical disorders, patients also suffer psychologically, their spirit is down or they come across as irritated ${ }^{(14) !}$. The medical discourse showed the lack of a clear distinction between physical and mental disorders, but a clear physical-psychological interrelationship.

Additionally, we found in the nursing discourse the importance of specialized knowledge in the psychiatric area: "(...) physical and mental disorders form an artificial distinction, since, owing to the intimate relationship between the body and spirit, it is rare that something that affects one part will not affect the other. The theory and practice of psychiatric nursing clarifies for the nurse what he or she is doing for the patient, psychologically. In the nurse's course, he or she learns to observe the patients and acquires the ability to keep psychological contact with him or her ${ }^{(15) ! " W i t h ~ t h e ~ i m p l e m e n t a t i o n ~ o f ~ t h e ~ M e n t a l ~ H y g i e n e ~}$ Program, psychiatry has become a field for public health nurses to work in, due to their influence on the community. The position public health nurses was considered strategic for having access to homes at any time, however, the course did not provide them with the necessary preparation: "Although the public health nurses have these advantages, they are not prepared. During the course, much of their efficiency is evaluated by the routine of hospital methods ${ }^{(19) "}$. 


\section{aINAL CONSIDERATIONS}

During the twenty two years that the Annals of Nursing existed, only nine articles about psychiatric nursing were published. In these articles, the discourse about nursing and the psychiatric nurse was made up, on one side, by propositions that were used by psychiatric physicians, for the active participation of nurses that sought to legitimize specialized knowledge for psychiatric nursing that was consistent with the transformations required in psychiatric practices at the time.

The authors defined psychiatric nursing, as well as the qualities that nurses need and the characteristics for psychiatric nursing care, which, little by little, arrived at a better definition in the body of the discourses of the nurses themselves, when moving away from the characteristics of subordination present in the medical discourse.

For dealing with discourses produced in the decades from 1930 to 1950, the nurse's job was highlighted within the proposed mental hygiene, where care in doctors' offices, outpatient care and home care was directed toward maintenance and preventing mental illness, which is why the public health nurse is mentioned as an agent of psychiatric attention. The understanding, by the physicians and nurses, of the complexity of psychiatric care is also evidenced, indicated the need for qualified formal preparation, recognizing a specialized knowledge for psychiatric nurses.

Thus, a nursing and psychiatric nurse model was characterized, focused on the registered nurse model, and not the other nursing staff at the time, which were dedicated, for the most part, to hospital-based psychiatric care.

Furthermore, we emphasize that the publications are fundamental elements for preserving the memory of the practice of nursing, and the existence of the Annals of Nursing journal is certainly valuable for the profession at present, as it recorded possible preterit circumstances to be recovered, reflected upon and recounted in this study.

\section{REFERENCES}

1. Costa JF. História da Psiquiatria no Brasil. Um corte ideológico. Rio de Janeiro: Garamond; 2007.

2. Oliveira WF. A compreensão do fenômeno psíquico na modernidade ocidental e a prática da saúde mental social e higiênica no Brasil. Cad. Bras. Saúde Mental. 2012; 4 (8): 160-165.

3. Carvalho AMT. Trabalho e higiene mental: processo de produção discursiva do campo no Brasil. História, Ciências, Saúde - Manguinhos. 1999; VI(1): 133-56.

4. Albertini P, Siqueira FZ, Tomé LA, Machado TL. Reich e o movimento de higiene mental. Psicologia em Estudo. 2007; 12 (2): 393-401.

5. Vilella SC, Scatena MCM. A enfermagem e o cuidar na área de saúde mental. Rev Bras. Enf. 2004; 57 (6): 738-41.

6. Foucault M. Arqueologia do Saber. Tradução Luiz F.B. Neves. Rio de Janeiro: Forense Universitária; 2012.

7. Foucault M. Microfísica do Poder. Rio de Janeiro: Graal; 2012.

8. Carvalho, A. Plano para melhorar o tratamento dos psicopatas. Revista Annaes de Enfermagem. 1946; 18: 26-34.

9. Peres MAA, Barreira IA. Uma Nova Enfermagem Psiquiátrica na Universidade do Brasil nos anos 60 do século XX. Esc. Anna Nery Rev. Enf. 2008; 12 (1): 108-14.

10. Amorin WM, Freire MAM. A enfermagem de saúde pública no Distrito Federal. Esc. Anna Nery Rev. Enf. 2008; 12 (1): 115-24.

11. Kirschbaum, DIR. História da enfermagem psiquiátrica no Rio Grande do Sul: parte I. Rev Gaúcha Enferm. 2003; 24(1): 95-108.

12. Olinto P. Aptidões e deveres da enfermeira de higiene mental. Revista Annaes de Enfermagem. 1933; 1(2): 16-17.

13. Carvalho A. 0 paciente mental agitado. Revista Annaes de Enfermagem. 1947; 16(23): 24-25.

14. Arruda J. Considerações gerais sobre a enfermagem psiquiátrica. Revista Annaes de Enfermagem. 1948; 1(2): 80-87.

15. Barcellos E. Enfermagem Psiquiátrica. Revista Annaes de Enfermagem. 1951; 4 (1): 86-89

16. Miranda FAN, Santos RCA, Azevedo DM, Fernandes RL, Costa TS. Fragmentos históricos da assistência psiquiátrica no Rio Grande do Norte, Brasil. Rev. Gaúcha Enferm. 2010 set;31(3):475-82.

17. Padilha MIC, Sobral VRS, Leite LMR, Peres MAA, Araujo AC. Enfermeira - A construção de um modelo a partir do discurso médico. Rev Escola de Enfermagem USP. 1997; 31(3): 437-51.

18. Foucault M. As palavras e as coisas. $4^{a}$ ed. São Paulo: Martins Fontes; 1987.

19. Santos EM. A enfermeira de saúde pública e a higiene mental. Revista Annaes de Enfermagem. 1951; 4(4): 311-14.
Author's address:

Maria Angélica de Almeida Peres

Rua Afonso Cavalcanti, 275, Cidade Nova

20211-110, Rio de Janeiro, RJ

E-mail: angelica.ufrj@uol.com.br
Received: 02.02.2012

Approved: 03.12.2013 